\title{
N,O-Nucleosides from Ene Reaction of (Nitrosocarbonyl)mesitylene with Crotyl Alcohol: Selectivity, Scope, and Limitations
}

\author{
Serena Carosso \\ Misal Giuseppe Memeo ${ }^{a}$ \\ Bruna Bovio ${ }^{a}$ \\ Elena Vallettab \\ Beatrice Macchía \\ Paolo Quadrelli*a \\ ${ }^{a}$ Department of Chemistry, University of Pavia, Viale \\ Taramelli 12, 27100 Pavia, Italy \\ paolo.quadrelli@unipv.it \\ ${ }^{b}$ Department of System Medicine, University of Rome \\ Tor Vergata, Via Montpellier 1, 00133 Roma, Italy
}

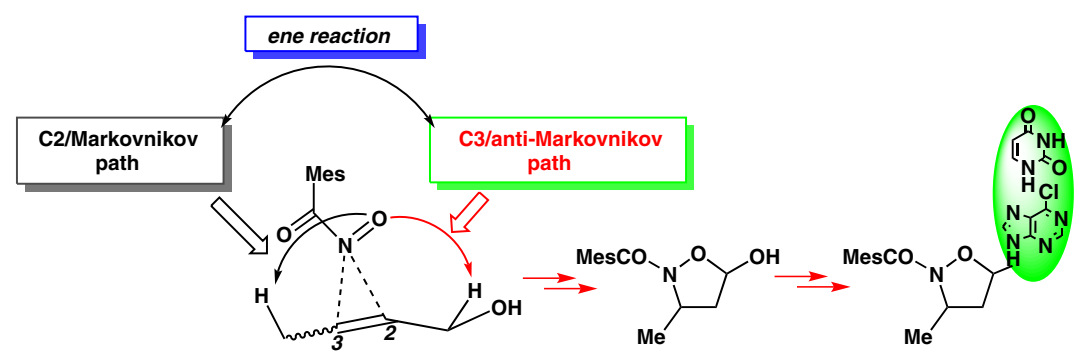

methylbut-2-en-1-ol (Scheme 1). ${ }^{6}$ 3-Methylbut-2-en-1-ol can be regarded as a trisubstituted allylic alkoxy olefin, and the allylic hydrogens on the more congested side of the alkene are exclusively abstracted (the 'cis effect'), thus resembling singlet oxygen behavior.

Abstract The (nitrosocarbonyl)mesitylene intermediate undergoes an ene reaction with crotyl alcohol, affording two regioisomeric adducts in fair yields. The sterically demanding (nitrosocarbonyl)mesitylene slightly shifts the C2/Markovnikov orientation towards a C3/antiMarkovnikov pathway, affording a 5-hydroxyisoxazolidine that serves as a synthon for the preparation of N,O-nucleoside analogues through the Vorbrüggen protocol. The selectivity of the ene reaction is discussed in the light of $\mathrm{C}=\mathrm{C}$ bond polarization and steric effects. The structures of the $\mathrm{N}, \mathrm{O}$-nucleosides are assigned and discussed on the basis of spectroscopic observations and $\mathrm{X}$-ray analysis.

Key words N,O-nucleosides, ene reaction, nitroso carbonyls, crotyl alcohol, Vorbrüggen protocol

The ene reactions of aromatic nitrosocarbonyl intermediates $\mathbf{1}$ (Scheme 1 ) with allylic alkoxy olefins were investigated and the synthesis of $\mathrm{N}, \mathrm{O}$-nucleoside analogues through the Vorbrüggen protocol was proposed. ${ }^{1}$ The Chiacchio and Romeo groups recently described the synthesis of truncated phosphonated C-1'-branched N,O-nucleosides as HIV inhibitors or inducers of apoptosis based on 1,3-dipolar cycloadditions of nitrones with vinyl acetate, followed by coupling with silylated nucleobases. ${ }^{2}$ The same approach was also followed by the research groups of Bortolini and Maiuolo for the synthesis of antiproliferative drugs. ${ }^{3}$ The 1,3 -dipolar cycloaddition synthetic strategy is a valuable method for spacer substitution in classical nucleosides. Furthermore, the introduction of a side chain led to several branched nucleosides which were found to be potential antitumor or antiviral agents, ${ }^{4}$ and an interesting cytoxicity and apoptotic activity was also observed. ${ }^{5}$ Our alternative for the synthesis of $\mathrm{N}, \mathrm{O}$-nucleosides relies upon the mild oxidation of aromatic nitrile oxides with tertiary amine $\mathrm{N}$-oxides to generate the nitrosocarbonyl intermediates 1 and the ene reaction with allylic alcohols such as 3-

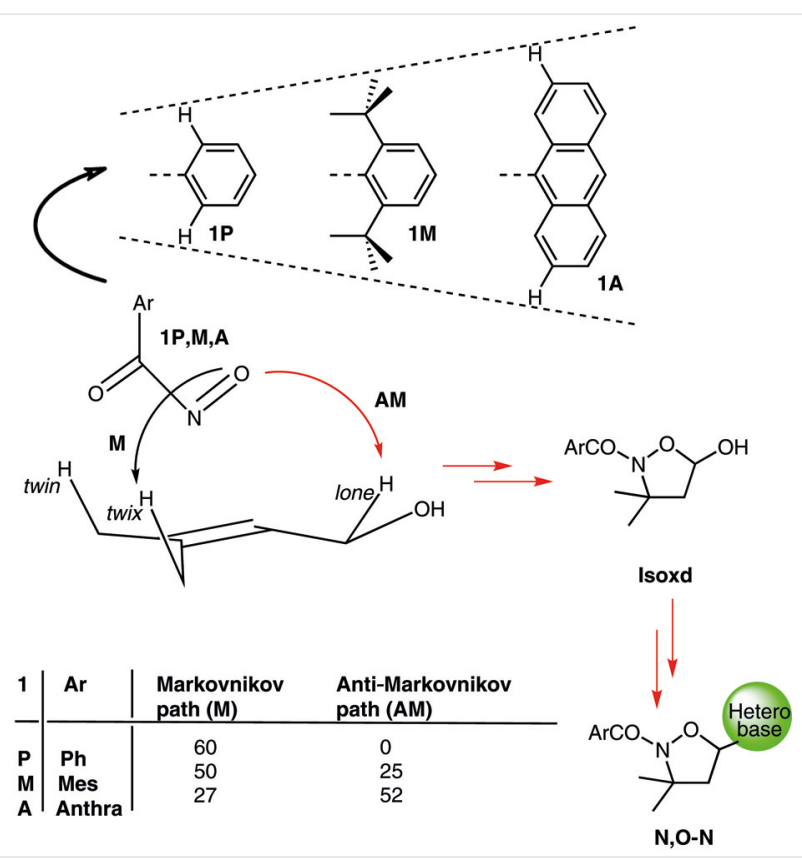

Scheme 1 Ene reaction of nitrosocarbonyls 1 with 3-methylbut-2-en1-ol and synthesis of isoxazolidine nucleosides

The canon (a general rule) for these reactions is that they proceed straightforwardly to the ene adducts in accordance with the prevailing $\mathrm{HOMO}_{\text {(olefin) }}-\mathrm{LUMO}_{\text {(nitrosocarbonyl) }}$ interaction, somewhat enforced by the polarization of the $\mathrm{C}=\mathrm{C}$ bond induced by the slightly electron-withdrawing group $\mathrm{CH}_{2} \mathrm{OH}^{7}{ }^{7}$ (Nitrosocarbonyl)benzene 1P $(\mathbf{P}=$ phenyl) follows a Markovnikov (M) orientation and preferentially 
abstracts the twix hydrogens over the lone ones. With the more sterically demanding (nitrosocarbonyl)mesitylene $(\mathbf{1} \mathbf{M} ; \mathbf{M}=$ mesityl), the Markovnikov directing effect is diminished and twix and lone abstraction are comparable (Scheme 1). ${ }^{8}$

The anti-Markovnikov (AM) pathway becomes the preferred one when the bulkier anthracene aromatic ring replaces mesitylene in the nitrosocarbonyl structure $\mathbf{1 A}(\mathbf{A}=$ anthryl). ${ }^{1}$ The anti-Markovnikov route leads to enol formation and subsequent cyclization to the isoxazolidine Isoxd, resembling the structures obtainable through nitrogen additions to vinyl acetate derivatives (Scheme 1). By adapting the Vorbrüggen protocol, a library of N,O-nucleosides N,O$\mathbf{N}$ was prepared from commercially available uracils and purines. ${ }^{1,9}$

On pursuing our research in nitrosocarbonyl ene reactions, we extended the studies to another allylic alcohol, the disubstituted crotyl alcohol, which was allowed to react in the presence of the mesitylene nitrosocarbonyl $\mathbf{1 M}$. The products of the ene reaction were characterized and the structures were assigned, allowing a closer examination of the selectivity outcome and disclosing new synthetic applications. The diastereoisomeric isoxazolidines deriving from formal anti-Markovnikov addition to the alcohols are presented as valuable synthons toward the preparation of new $\mathrm{N}, \mathrm{O}$-nucleoside analogues. The structures were assigned on the basis of the corresponding spectroscopic data as well as $\mathrm{X}$-ray analysis and the regioselectivity outcome in purine derivatives was also solved with the aid of NMR experiments and diffractometric investigations.

Addition of a dichloromethane $\left(\mathrm{CH}_{2} \mathrm{Cl}_{2}\right)$ solution of mesitonitrile oxide (MNO) to a stirred solution of $\mathrm{N}$-methylmorpholine $\mathrm{N}$-oxide (NMO, 1.1 equiv) in $\mathrm{CH}_{2} \mathrm{Cl}_{2}$ in the presence of an excess (5 equiv) of crotyl alcohol (mixture of cis and trans) afforded, after standing overnight at r.t., the ene adducts $\mathbf{2}$ and $\mathbf{3}$ (Scheme 2), which were isolated by chromatographic separation of the reaction mixture in $50 \%$ and $23 \%$ yield, respectively.

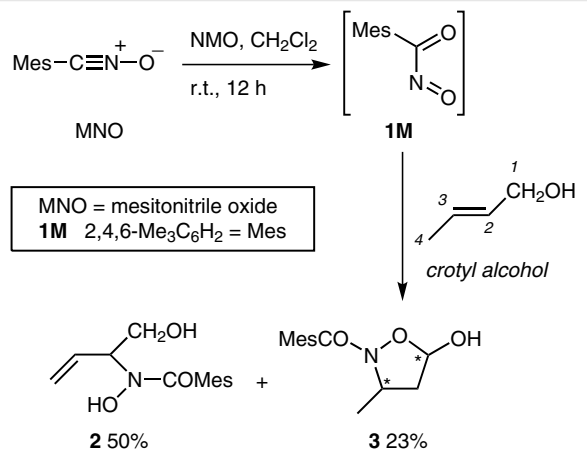

Scheme 2 Ene reactions of the (nitrosocarbonyl)mesitylene intermediate with crotyl alcohol
The structures of the isolated ene adducts were determined by the corresponding analytical and spectroscopic data. In the ${ }^{1} \mathrm{H}$ NMR spectrum of the ene adduct 2 , the typical olefinic methylene signals are found as doublets at $\delta=$ 5.08 and 5.23 , while the olefinic methine proton is typically found more deshielded at $\delta=5.95$ as a multiplet. The $\mathrm{N}-\mathrm{OH}$ group is found strongly deshielded as a broad signal at $\delta=$ 10.40. The other signals are found in the expected ranges for the reported structure; in particular, the $\mathrm{OH}$ group resonates at $\delta=3.34$ as a doublet, also shown in the IR spectrum at $3152 \mathrm{~cm}^{-1}$. Compound 2 is derived from the addition of (nitrosocarbonyl)mesitylene (1M) to the hydroxymethylene substituted carbon atom $\mathrm{C} 2$ of the double bond of crot$\mathrm{yl}$ alcohol. Structure $\mathbf{2}$ belongs to the family of compounds obtained in previous work ${ }^{1,9}$ from 3-methylbut-2-en-1-ol in full accordance with a Markovnikov orientation. ${ }^{8,10}$ In the present case of crotyl alcohol, it is somewhat inappropriate to consider the carbon atom $\mathrm{C} 2$ the site of Markovnikov addition (C2/M addition), because of the 1,2-disubstitution of the $\mathrm{C}=\mathrm{C}$ bond of the alcohol; however, this is useful and done for the sake of comparison with previous results. ${ }^{1,9}$

If the addition of the electrophilic (nitrosocarbonyl)mesitylene (1M) occurs at the C3 carbon atom, the product of the ene reaction is represented by the 5-hydroxyisoxazolidine 3; the primary adduct is the enol $\mathbf{4}$ that evolves into the non-isolable aldehyde $\mathbf{5}$, which undergoes cyclization to the stable hemiacetal 3 (Scheme 3). This type of 5-hydroxyisoxazolidine is usually prepared by reaction of hydroxamic acids and $\alpha, \beta$-unsaturated aldehydes ${ }^{11}$ or through the ene protocol of nitrosocarbonyls and allylic alcohols. ${ }^{1}$ As in the previous cases, ${ }^{1,9}$ the origin of isoxazolidine $\mathbf{3}$ was undoubtedly attributed to the diminishing of the $\mathrm{C} 2 / \mathrm{M}$ addition due to the more sterically demanding mesityl group that activates the C3/AM pathway. ${ }^{8-10}$

The structure of $\mathbf{3}$ was assigned on the basis of the corresponding analytical and spectroscopic data. All the NMR spectra indicate the presence of an inseparable mixture of diastereoisomers in a 2:1 ratio 2:1 (Schemes 2 and 3). In the case of the major diastereoisomer, the ${ }^{1} \mathrm{H}$ NMR $\left(\mathrm{CDCl}_{3}\right)$ spectrum indicates the presence of a deshielded proton at $\delta$ $=5.89$ as a triplet $(\mathrm{J}=4 \mathrm{~Hz})$ coupled with two protons at $\delta=$ 2.03 and 2.51. The methyl group is found at $\delta=1.03$ as a doublet $(J=6 \mathrm{~Hz})$, because of the coupling with the methine proton at $\delta=3.98(\mathrm{q}, J=6 \mathrm{~Hz})$. The $\mathrm{OH}$ group is confirmed by the corresponding IR spectrum (strong band at $3284 \mathrm{~cm}^{-1}$ ). The ${ }^{13} \mathrm{C}$ NMR spectrum presents a signal at $\delta=98.3$ resembling an acetal-type carbon atom. The structure assignment as shown in Scheme 2 was confirmed beyond any reasonable doubt from the X-ray analysis (Figure 1, see also Supporting Information).

The 5-hydroxy-isoxazolidine $\mathbf{3}$ obtained from the ene reaction of (nitrosocarbonyl)mesitylene (1M) with crotyl alcohol was used as a synthon to prepare $\mathrm{N}, \mathrm{O}$-nucleoside analogues by adapting the Vorbrüggen protocol ${ }^{12}$ as well as 


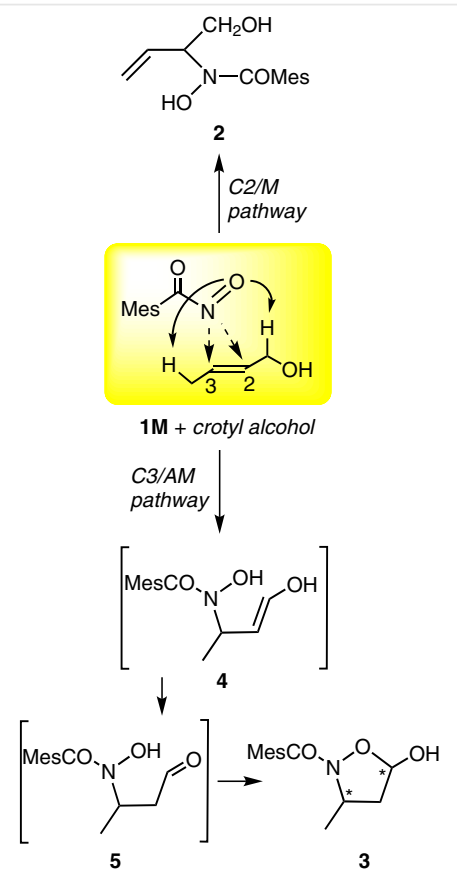

Scheme $3 \mathrm{C} / \mathrm{M}$ versus C3/AM pathways: the formation of the 5-hydroxyisoxazolidine ring

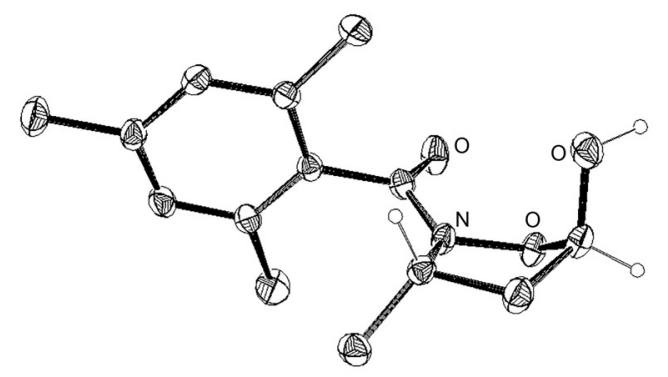

Figure 1 X-ray crystal structure of ene adduct 3 (mixture of diastereoisomers)

other procedures for similar compounds. ${ }^{5,13}$ The diastereoisomeric acetyl derivatives $\mathbf{6 a}, \mathbf{b}$ were prepared according to standard procedures (Scheme 4). ${ }^{1,14}$ The acetylated compounds were obtained in nearly quantitative yield, separated by column chromatography and fully characterized. The acetylated compounds $\mathbf{6 a}$ and $\mathbf{6 b}$ are diastereoisomers, each one obtained as a racemic mixture of enantiomers, isolated in $45 \%$ and $47 \%$ yields, respectively. The structures reported in Scheme 4 were assigned on the basis of the corresponding analytical and spectroscopic data and the diastereoisomeric outcome was determined by NOESY experiments. In the ${ }^{1} \mathrm{H}$ NMR spectra $\left(\mathrm{CDCl}_{3}\right)$, the presence of the acetyl groups is shown by two singlets at $\delta=2.06$ for $\mathbf{6 a}$ and at $\delta=1.90$ for $\mathbf{6 b}$, while in the corresponding ${ }^{13} \mathrm{C}$ NMR spectra two additional signals corresponding to $\mathrm{C}=\mathrm{O}$ groups were both detected at $\delta=169.0$. The NOESY experiments allowed for the attribution of the reported stereochemistry (NOE correlations in red in Scheme 4). In the stereoisomer 6a, the proton at $\delta=6.33$ correlates with one of the two methylene protons at $\delta=2.25$, while the other one at $\delta=$ 2.72 correlates with the $\mathrm{CH}-\mathrm{N}$ proton found at $\delta=4.65$. In the stereoisomer $\mathbf{6 b}$, the proton at $\delta=6.18$ correlates with one of the two methylene protons at $\delta=2.22$, which displays a second correlation with the $\mathrm{CH}-\mathrm{N}$ proton found at $\delta=4.62$; this relationship is also confirmed by the correlation between the methyl group at $\delta=1.43$ with the methylene proton at $\delta=2.20$ (Scheme 4 ).

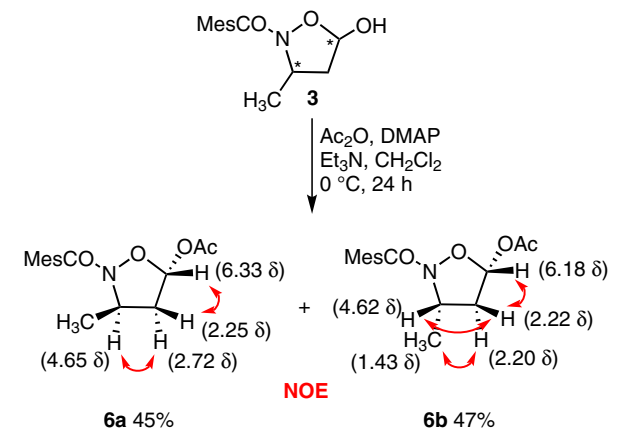

Scheme 4 Acetylation of 5-hydroxyisoxazolidine 3 ( ${ }^{1} \mathrm{H}$ NMR $\delta$ for $\mathbf{6 a}$ and $\mathbf{6 b}$ given in parentheses)

To prepare the uracil derivatives, the Vorbrüggen protocol can be applied both on a previously silylated heterobase or on a commercial compound in the presence of silylating agents. ${ }^{12,15}$ In the cases at hand, we report the syntheses conducted on the commercial uracil base used in the presence of an in situ prepared silylating agent, bis(trimethylsilyl)acetamide (BSA) and trimethylsilyl trifluoromethanesulfonate (TMSOTf) as reaction promoter. ${ }^{16}$

The acetylated isoxazolidines $\mathbf{6 a}$ and $\mathbf{6 b}$ were added under nitrogen atmosphere at r.t. to a solution of uracil (2 equiv) and $\mathrm{BSA}$ ( 2 equiv) and the solutions became clear after boiling in $\mathrm{CH}_{2} \mathrm{Cl}_{2}$ for a couple of hours. The mixtures were then ice-cooled at $0{ }^{\circ} \mathrm{C}$ and TMSOTf ( 1 equiv) was added and the reaction mixtures refluxed overnight (Scheme 5). The desired compounds $\mathbf{7 a , b}$ were obtained as a white solids separated by column chromatography and fully characterized. Nucleoside analogues $\mathbf{7 a , b}$ were isolated in good yields (37-49\%) and their structures determined by analytical and spectroscopic data. The reactions were performed on a single diastereoisomer of the starting compound and gave mixtures of both diastereoisomers of the products belonging to the family of uracil derivatives in a nearly $1: 1$ ratio. Table 1 reports the yields, physicochemical data and the relevant ${ }^{1} \mathrm{H}$ NMR spectroscopic data supporting the structural assignments given in Scheme 5.

The ${ }^{1} \mathrm{H}$ NMR spectra of uracil derivatives $7 \mathbf{a}, \mathbf{b}$ were typical for this type of compound, with doublets $(\mathrm{J}=8 \mathrm{~Hz})$ at $\delta=$ 5.69 and $7.70(\mathbf{7 a})$ and $\delta=5.63$ and $7.65(\mathbf{7 b})$, clearly related 
Table 1 Yields and Physicochemical and Spectroscopic Data of Compounds 7a,b

\begin{tabular}{|c|c|c|c|c|c|c|}
\hline & $\mathrm{mp}\left({ }^{\circ} \mathrm{C}\right)^{\mathrm{a}}$ & Yield from $\mathbf{6 a}(\%)$ & Yield from $\mathbf{6 b}(\%)$ & $\mathrm{IR}\left(\mathrm{cm}^{-1}\right) \mathrm{v}_{\mathrm{NH}}$ & $\mathrm{v}_{\mathrm{C}=\mathrm{O}}$ & \\
\hline $7 a$ & $>210$ & 49 & 46 & 3164 & 1724, 1669 & \\
\hline \multirow[t]{3}{*}{$7 b$} & $>210$ & 47 & 37 & 3173 & 1702,1637 & \\
\hline & ${ }^{1} \mathrm{H}$ NMR $(\delta$, DMSO) & & & & & \\
\hline & $\mathrm{CH}_{2}$ & $\mathrm{CH}-\mathrm{N}$ & $=\mathrm{CH}-\mathrm{CO}$ & $\mathrm{O}-\mathrm{CH}-\mathrm{Ur}$ & $\mathrm{N}-\mathrm{CH}=$ & $\mathrm{NH}$ \\
\hline $7 a$ & $2.29,2.93(\mathrm{~m})$ & $4.67(\mathrm{~d})$ & 5.69 (d) & $6.19(\mathrm{t})$ & 7.70 (d) & $11.33(\mathrm{~s})$ \\
\hline $7 b$ & $2.50,2.95(\mathrm{~m})$ & $4.84(\mathrm{~m})$ & $5.63(d)$ & 6.27 (d) & 7.65 (d) & $11.33(\mathrm{~s})$ \\
\hline
\end{tabular}

a From ethanol.<smiles>CC(=O)OC1CCC(C)N1OC(C)=O</smiles>

$6 a$<smiles>O=c1cc[nH]c(=O)[nH]1</smiles>$$
(1.50
$$

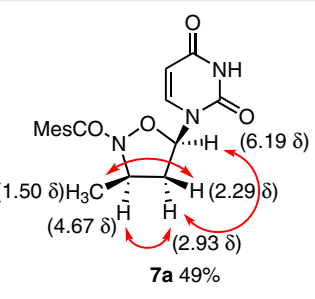

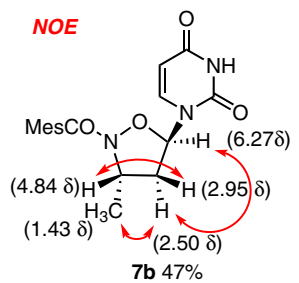

$6 b$

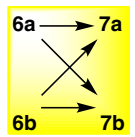

Scheme 5 Synthesis of uracil isoxazolidine nucleoside analogues by the Vorbrüggen protocol

to the uracil double bond, while both imide NH groups appeared highly deshielded at $\delta=11.33$ as singlets. The other signals are consistent for the isoxazolidine structure. The configurations of the two diastereoisomers $\mathbf{7 a}$ and $\mathbf{7 b}$ were assigned on the basis of NOESY experiments and the correlations are reported in red in Scheme 5. Compound 7a shows the uracil ring cis-related to the methyl group of the isoxazolidine ring, while in compound $\mathbf{7 b}$ the uracil is found trans to the methyl group. It must further be pointed out that the two products exist as racemic mixtures of enantiomers. The most intriguing fact in the synthesis of these nucleoside analogues is that both the diastereoisomers are obtained from each starting acetyl derivative: $\mathbf{6 a}$ gives a mixture of $\mathbf{7} \mathbf{a}$ and $\mathbf{7 b}$; the same happens if the reaction is conducted starting from $\mathbf{6 b}$ (see yellow inset in Scheme 5). These results furnished some insights on the operating mechanism of the Vorbrüggen protocol on substrates $\mathbf{6}$ and deserve a discussion (vide infra). For this reason, for preparative purposes, the reaction can be conduct- ed simply on a diastereoisomeric mixture of $\mathbf{6 a}, \mathbf{b}$, and products $7 \mathbf{a}$ and $\mathbf{7 b}$ can be separated once the reaction ends.

The uracil nucleoside analogues $\mathbf{7 a}$ and $\mathbf{7 b}$ could be submitted for biological evaluation without any further structural modifications, either for their antiviral behavior or, in other cases, to compare their activities with those of reported carbocyclic and heterocyclic structures. 5,13,17,18

To expand the synthetic applications of the Vorbrüggen protocol on the acetylated isoxazolidines $\mathbf{6 a}, \mathbf{b}$ and determine the scope and limitations of the method, ${ }^{19}$ we investigated the functionalization with the commercially available 6-chloropurine, being aware of the possible increasing

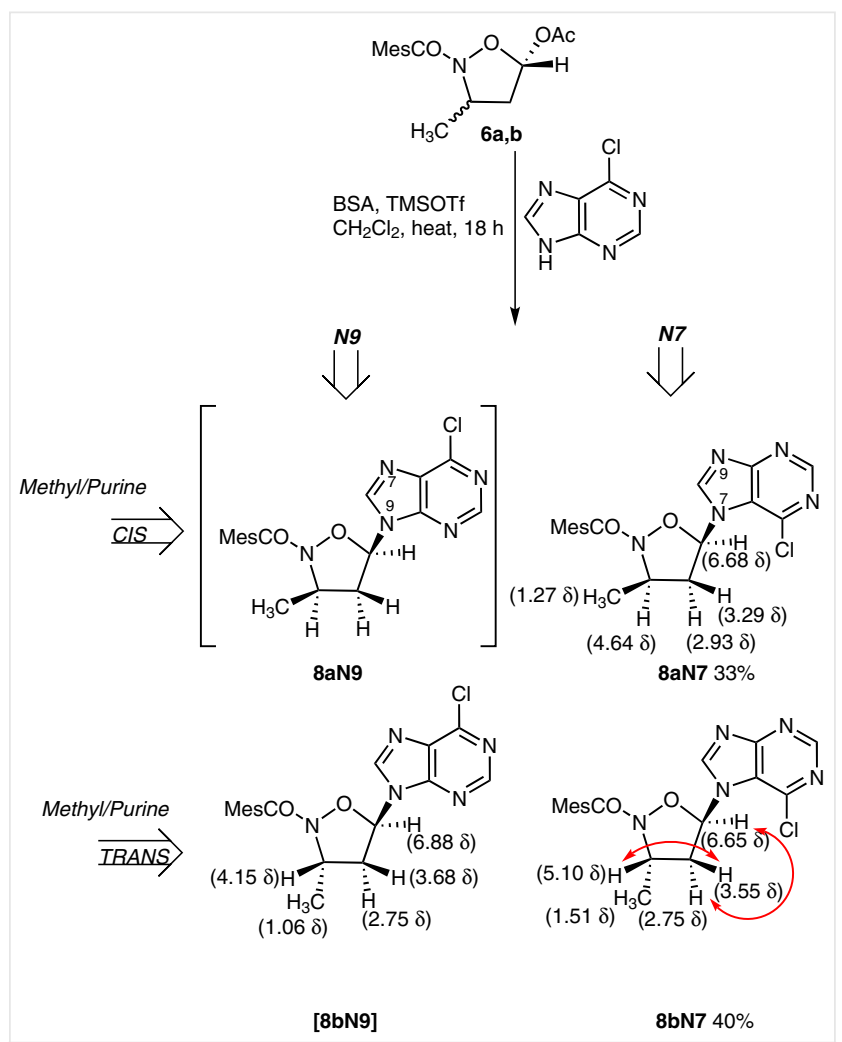

Scheme 6 Synthesis of 6-chloropurine isoxazolidine nucleoside analogues by the Vorbrüggen protocol 
Table 2 Yields and Physicochemical and Spectroscopic Data of Compounds 8a,b

\begin{tabular}{|c|c|c|c|c|c|c|}
\hline & $\mathrm{mp}\left({ }^{\circ} \mathrm{C}\right)^{\mathrm{a}}$ & Yield from $\mathbf{6 a}, \mathbf{b}$ (\%) & IR $\left(\mathrm{cm}^{-1}\right) \mathrm{v}_{\mathrm{c}=0}$ & $\mathrm{v}_{\mathrm{C}=\mathrm{N}}$ & & \\
\hline 8aN7 & $177-178$ & 33 & 1663 & 1635 & & \\
\hline 8aN9 & - & $N D^{\mathrm{b}}$ & - & - & & \\
\hline $8 b N 7$ & $>210$ & 40 (mix) & 1663 & 1624 & & \\
\hline \multicolumn{7}{|l|}{ 8bN9 } \\
\hline & \multicolumn{6}{|c|}{${ }^{1} \mathrm{H}$ NMR $(\delta$, DMSO) } \\
\hline & $\mathrm{CH}_{3}$ & $\mathrm{CH}_{2}$ & $\mathrm{CH}-\mathrm{N}$ & $\mathrm{O}-\mathrm{CH}-\mathrm{Pur}$ & $\mathrm{CH}=\mathrm{N}^{\mathrm{c}}$ & $\mathrm{CH}=\mathrm{N}^{\mathrm{d}}$ \\
\hline 8aN7 & $1.55(\mathrm{~d})$ & $3.21,3.00(\mathrm{~m})$ & $4.75(\mathrm{~m})$ & $6.62(t)$ & $9.22(s)$ & $8.83(\mathrm{~s})$ \\
\hline 8aN9 & - & - & - & - & - & - \\
\hline 8 bN7 & $1.51(\mathrm{~d})$ & $2.75,3.55(\mathrm{~m})$ & 5.10 (quin) & $6.65(d)$ & $8.90(\mathrm{~s})$ & $8.73(s)$ \\
\hline $8 b N 9$ & 1.06 (d) & $2.75,3.68(\mathrm{~m})$ & $4.15(\mathrm{~m})$ & 6.88 (d) & $8.96(\mathrm{~s})$ & $8.89(\mathrm{~s})$ \\
\hline
\end{tabular}

a From ethanol.

b $\mathrm{ND}=$ not detected

c Methine proton from imidazole ring of 6-chloropurine.

d Methine proton from pyrimidine ring of 6-chloropurine.

complexity of the reaction mixture. In fact, it is well known that the purine rings could give regioisomeric adducts at the N7 and N9 nitrogen atoms; ${ }^{9}$ if this is transferred to a substrate existing as a mixture of diastereisomers, the stereochemical outcome increases its complexity.

The acetylated isoxazolidines $\mathbf{6 a}, \mathbf{b}$ were added under a nitrogen atmosphere at r.t. to a solution of 6-chloropurine ( 2 equiv) and BSA ( 2 equiv) and the solutions became clear after boiling in $\mathrm{CH}_{2} \mathrm{Cl}_{2}$ for a couple of hours. The mixtures were then ice-cooled at $0{ }^{\circ} \mathrm{C}$ and TMSOTf ( 1 equiv) was added and the reaction mixtures were refluxed overnight. Scheme 6 reports on the structures of the four possible products.

On the basis of previous observations, the reaction was conducted on the mixture of the diastereoisomeric acetylated compounds $\mathbf{6 a}, \mathbf{b}$ to give a mixture of four possible diastereoisomeric products where the purine ring can be linked at the isoxazolidine moiety through the N7 and/or N9 nitrogen atoms. Two compounds $8 \mathbf{a}, \mathbf{b}$ were obtained as white solids separated by column chromatography and characterized. The purine nucleoside analogues 8a,b were isolated in moderate yields ( $33 \%$ and $40 \%$, respectively) and their structures were determined with analytical and spectroscopic data through a careful and detailed analysis in particular of the NMR data. Table 2 reports the yields, physicochemical data and the relevant ${ }^{1} \mathrm{H}$ NMR spectroscopic data supporting the structural assignments given in Scheme 6.

As reported, quite surprisingly, only two compounds were detected and separated from the reaction mixture. Both contain the 6-chloropurine rings coupled with the isoxazolidine moiety. The major task was the stereochemical assignment, since spectroscopic data alone give only a few suggestions on the relationship between the methyl group of the isoxazolidine ring and the purine ring. A defin- itive answer came from the X-ray crystal structure analysis of compound 8a; the structure 8aN7 was assigned. Combining information from the diffractometric analysis and the chemical shift data from the NMR spectra, it was possible to define the stereochemical outcome of this reaction (Figure 2).

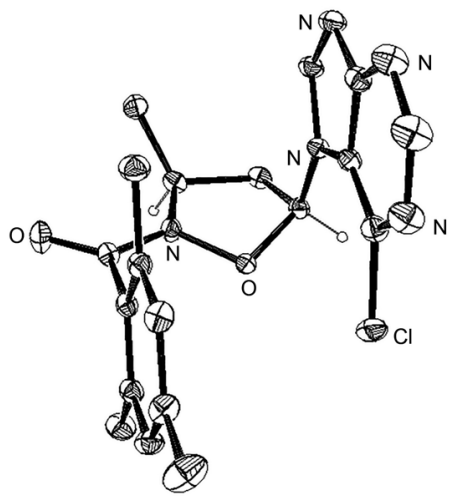

Figure 2 X-ray crystal structure of compound 8aN7

For compound $\mathbf{8 b}$, only the spectroscopic data are available to determine the structure. NOESY experiments gave successful answers on the stereochemistry of $\mathbf{8 b}$, which was confirmed to belong to the trans series of the purine adducts, i.e. the purine ring and the methyl group are transrelated on the isoxazolidine moiety, as shown in Scheme 6, where the NOE correlations are indicated by red arrows. In the NMR spectrum we have also detected a minor component relative to $\mathbf{8 b}$, not separable from the major; the spectroscopic (NMR) data are reported in Table 2. The signals do not correspond to hindered rotations, since we have verified the matter through variable temperature experiments, and no signal coalescence occurred in the spectra recorded 
in DMSO. Compound $\mathbf{8 b}$ is made up of an inseparable mixture of two products, and we have tentatively assigned the reported structures on the basis of NMR observations.

In Table 2 the NMR signals related to compound $\mathbf{8 b}$ were separately assigned to the regioisomers $\mathbf{8 b N 7}$ (major) and 8bN9 (minor). This was done after comparison of the chemical shifts of the representative protons. These values for the 8bN7 regioisomer are more deshielded than those of the 8bN9 regiosiomer, corresponding well with the observed values of solely compound 8aN7. Due to the lack of pure compounds available, these products were not used for biological evaluation.

We investigated the ene reactions of (nitrosocarbonyl)mesitylene, generated through the mild oxidative protocol with NMO, with crotyl alcohol, a 1,2-disubstituted allylic alcohol. The fast oxidation process of nitrile oxide to the nitrosocarbonyl intermediate prevents a possible side reaction, i.e. the addition of the electrophilic nitrile oxide to the reactive 1,2-disubstituted allylic alcohols. In fact, the alcohol employed is prone to undergo 1,3-dipolar cycloaddition, being a slightly reactive dipolarophile. ${ }^{20}$ From the reaction mixtures, the presence of adducts between the aromatic nitrile oxides and crotyl alcohol were not observed in isolable amounts, even in the crude mixtures.

(Nitrosocarbonyl)mesitylene (1M) adds to crotyl alcohol affording adducts 2 and 3, which derive, respectively, from the preferred $\mathrm{C} 2 / \mathrm{M}$ path or the competitive $\mathrm{C} 3 / \mathrm{AM}$ route in the ene reaction (Scheme 7). ${ }^{1,8,9}$ The results are discussed in terms of two grounds: (a) polarization of the $\mathrm{C}=\mathrm{C}$ bond and (b) steric effects.

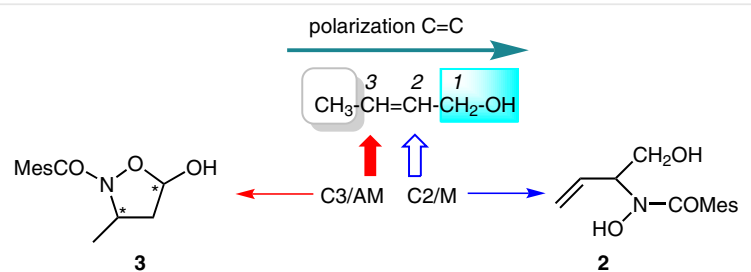

Scheme 7 Substituent effect on the $\mathrm{C}=\mathrm{C}$ bond polarization in crotyl alcohol

In crotyl alcohol, the methyl and the hydroxymethylene groups are the substituents of the $\mathrm{C}=\mathrm{C}$ bond and both concur to establish the polarization towards the $\mathrm{C} 2$ carbon atom as shown in Scheme $7 .^{7}$ The methyl group (C4) is a modest donor, while hydroxymethylene (C1) is slightly electron withdrawing. As a consequence, the electron-rich C2 carbon atom is apt to receive the addition of the electrophilic nitrosocarbonyl intermediate. The subsequent abstraction of the allylic hydrogen on the methyl group leads to the Markovnikov (M) preference (adduct 2 ) of the ene reaction in accordance with the prevailing $\mathrm{HOMO}_{(\text {olefin) }}{ }^{-}$ $\mathrm{LUMO}_{\text {(nitrosocarbonyl) }}$ interaction. However, the reaction conducted with the sterically demanding (nitrosocarbonyl)me- sitylene (1M) does not leave the C3/AM path unpopulated, and this deserves a brief comment. The canon described above is respected.

In previous work ${ }^{1,9}$ we demonstrated that increasing the bulkiness of an aromatic substituent on a nitrosocarbonyl moiety leads to the AM ene reaction pathway becoming preferred over the M path. The mesitylene ring is located in the middle of this ranking (Scheme 8 , cf. Scheme 1) and the regioselectivity is akin to previous results obtained with 3methylbut-2-en-1-ol. From a mechanistic point of view, we pointed out that, when bulkier substituents replace the phenyl group (Schemes 1 and 8), the M path is raised energetically because of a steric effect and the AM path is favored affording a mixture of regioisomeric compounds. We have recently detailed the selectivity outcome in the ene reaction of (nitrosocarbonyl)mesitylene (1M) with trisubstituted olefins, ${ }^{8}$ and the results show the remarkable influence of the nitrosocarbonyl substituent on the selectivities in ene reactions. Model calculations on the reaction of $\mathbf{1 M}$ with tetramethylethylene (TME) shed light on the factors involved in the varying selectivities. In these reactions of trimethylethylene, the M path is favored in the case of (nitrosocarbonyl)benzene, while steric hindrance in the approach of 1M compensates somewhat its electronic preference and mixtures of $\mathrm{M}$ and $\mathrm{AM}$ adducts are formed (Figure 3 ). This mechanism was found at work also in the case of 3methylbut-2-en-1-ol and remarkably influences and enforces the selectivity in the reaction of (nitrosocarbonyl)anthracene with 3-methylbut-2-en-1-ol. ${ }^{1}$

As we have demonstrated, ${ }^{8}$ in the reactions of (nitrosocarbonyl)benzene with TME, the transition structure (TS) of the addition step shows no special hindrance between the
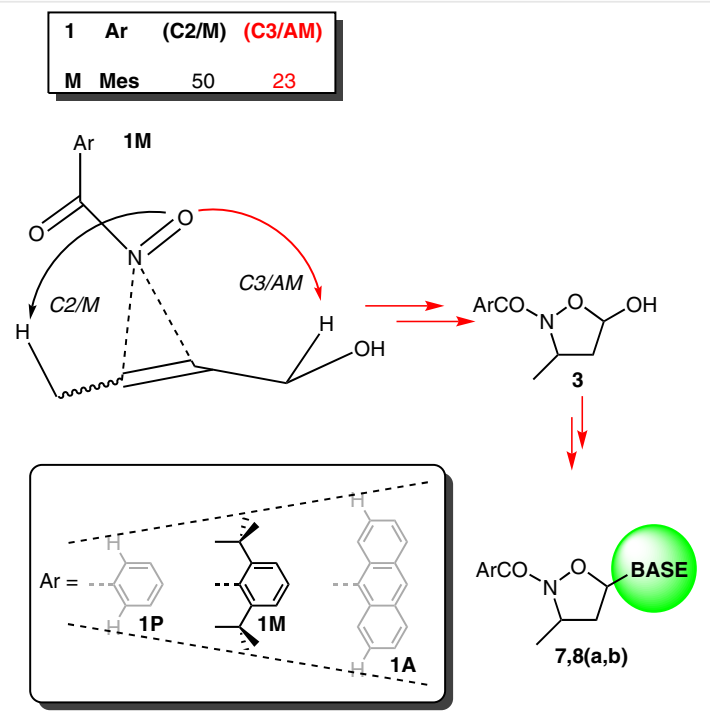

Scheme 8 Competition between C2/M and C3/AM ene reaction pathways 

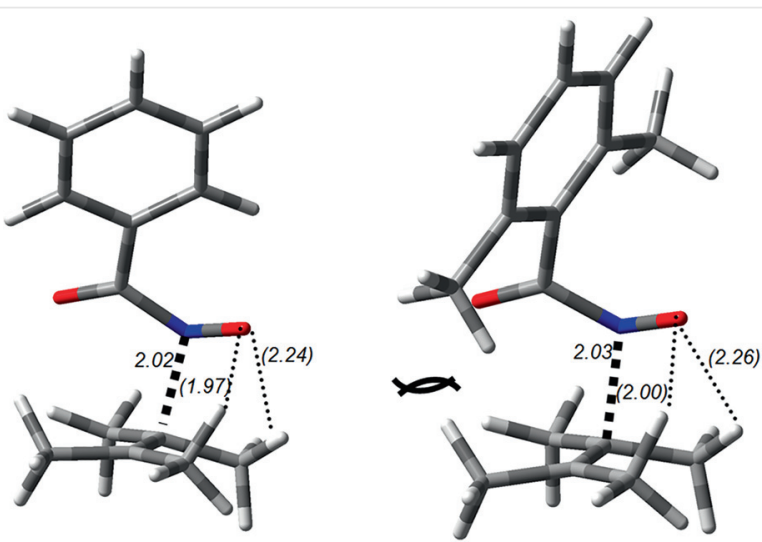

Figure 3 Side view of the B3LYP/6-31C* transition structures for the reactions of tetramethylethylene with (nitrosocarbonyl)benzene and 2,6-dimethylbenzene ${ }^{8}$

addends while in the TS of $\mathbf{1 M}$ the mesityl group is twisted out of the nitrosocarbonyl plane as usual, causing unfavorable steric crowding between its ortho methyl and the 'trans' distal TME methyl as depicted in Figure 3. Moving to the case of crotyl alcohol, the evaluation of the steric effect is depicted in Figure 4. Taking into account that crotyl alcohol was used as a mixture of the cis and trans isomers, four possible approaches must be considered, two for the $\mathrm{C} 2 / \mathrm{M}$ orientation and two for the C3/AM orientation for both the cis and trans crotyl alcohol. For the sake of comparison, in the inset of Figure 4 the same orientations for the $M$ and AM pathways are shown for (nitrosocarbonyl)mesitylene (1M) and 3-methylbut-2-en-1-ol. ${ }^{1}$ The steric clashes (red lines, Figure 4, inset) operating in the $\mathrm{M}$ path in the reaction of $\mathbf{1 M}$ with 3-methylbut-2-en-1-ol are important steric effects that raise the energy of the M path, making it comparable with the AM route. The model maintains its validity.

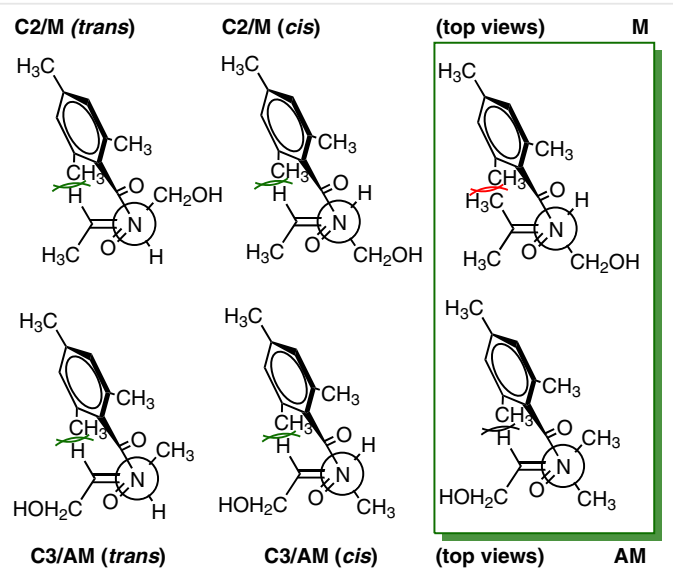

Figure 4 Top views of the $\mathrm{C} 2 / \mathrm{M}$ and C3/AM ene additions between crotyl alcohol and (nitrosocarbonyl)mesitylene; inset: comparison of the $\mathrm{M}$ and $\mathrm{AM}$ paths in the ene reaction of (nitrosocarbonyl)mesitylene with 3-methylbut-2-en-1-ol
These clashes are still able to determine the same energetic effect on the TSs relative to the M pathway, even in the reaction with crotyl alcohol. This result was hardly predictable and had to be verified by this study. However, the steric effect in the case at hand is weakened because of the double substitution of the ene partner.

The lack of the third methyl group makes it difficult to have comparable energies for the two regiochemical orientations of the ene reaction on the basis of steric effects. In fact, in both the cis and trans arrangements of the crotyl alcohol, the distorted mesitylene group of the enophile points the ortho methyl towards a simple hydrogen atom. Nevertheless, the crotyl alcohol contributes, although quantitatively less, in orienting the reaction towards the AM path significantly, despite the fact that the majority of the ene products result from the $\mathrm{M}$ route. The ene addition according to the C3/AM pathway is not equal to zero and the obtained results suggest the intrinsic relevance of the AM path. It results in enol formation and, although unstable, this intermediate immediately undergoes subsequent cyclization to the highly stable isoxazolidine structure. This can be the unexpected and powerful driving force able to somewhat compensate the electronic bias of the ene reaction and the weakness of steric effects.

5-Hydroxyisozaxolidine 3, resembling structures obtainable through nitrone cycloadditions, is a useful synthon for the preparation of $\mathrm{N}, \mathrm{O}$-nucleoside analogues. By adapting the Vorbrüggen protocol, ${ }^{12,19}$ as well as known procedures for similar compounds, ${ }^{5,13}$ we have prepared the uracil derivatives $\mathbf{7 a , b}$ and the 6 -chloropurine derivatives $\mathbf{8 a}, \mathbf{b}$ in good to excellent yields, even though in this last case the synthesis displays some deficiencies.

The stereochemical outcome of the functionalization reactions with in situ silylated heterobases according to the Vorbrüggen protocol clearly demonstrates that the triflatepromoted replacement of the acetoxy group with the heterobase in isoxazolidine $\mathbf{6}$ proceeds through the stabilized cation $\mathbf{6}^{\prime}$ as shown in Scheme 9. Due to the flatness of cat-

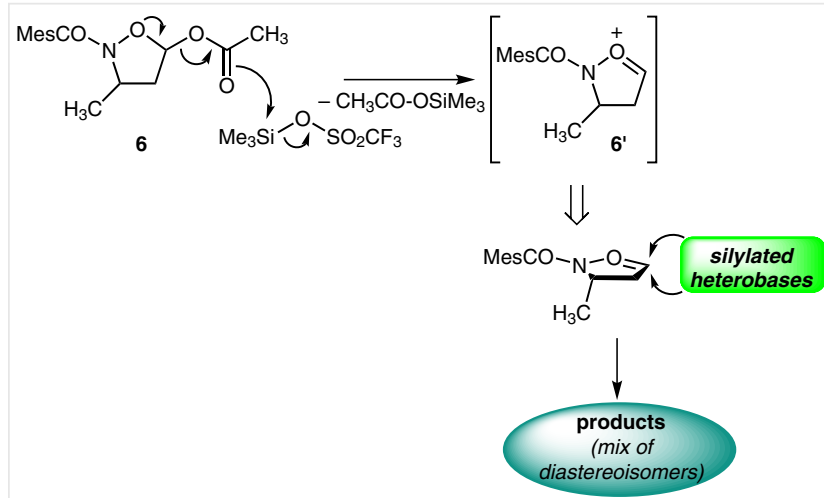

Scheme 9 Mechanism of triflate-promoted heterobase substitution on 5-acetoxyisoxazolidine 6 
ion $\mathbf{6}^{\prime}$, the addition of the silylated heterobase occurs on both faces of the isoxazolidine ring, producing mixtures of diastereoisomeric products.

These products constitute a new class of nucleoside analogues with different heterobases, easily inserted on the isoxazolidine ring. Their potential in term of biological activity is totally unexplored, but we believe could be promising, if we compare the new nucleoside structures with those of known compounds, both hetero- and carbocyclic, recently reported in the literature to be interesting adenosine receptor agonists. ${ }^{21}$

With the exception of compounds $\mathbf{8 a}, \mathbf{b}$, both the uracil derivatives $\mathbf{7 a} \mathbf{a}, \mathbf{b}$ were sent to the Southern Research Institute (SRI) of Birmingham (AL, USA) within the Tuberculosis Antimicrobial Acquisition and Coordinating Facility (TA$\mathrm{ACF}$ ) program and tested against the Mycobacterium tuberculosis H37Rv in BACTEC 12B medium using the microplate Alamar Blue Assay. ${ }^{22}$ The minimum inhibition concentration (MIC $\mu \mathrm{g} / \mathrm{mL}$ ) were found $>6.03$ for all the compounds with \%Inh in the range 22-34. Further antiviral, antitumor, and apoptosis tests are currently under evaluation.

All melting points are uncorrected. Elemental analyses were done on an elemental analyzer. ${ }^{1} \mathrm{H}$ and ${ }^{13} \mathrm{C}$ NMR spectra were recorded on a $300 \mathrm{MHz}$ spectrometer (solvents specified). Chemical shifts are expressed in $\mathrm{ppm}$ relative to internal tetramethylsilane. IR spectra (Nujol) were recorded on a spectrophotometer. Column chromatography and TLC were carried out on silica gel $\mathrm{H} 60$ and $\mathrm{GF}_{254}$, respectively; eluants were cyclohexane-EtOAc, 9:1 to pure EtOAc; when specified, pure $\mathrm{CHCl}_{3}$ to $\mathrm{CHCl}_{3}-\mathrm{MeOH}$, 9:1 was used for the nucleosides syntheses. Crotyl alcohol (mixture of cis and trans, 96\%) and cinnamyl alcohol $(98 \%)$ were purchased from chemical suppliers. Mesitonitrile oxide (MNO) was obtained by oxidation of 2,4,6-trimethylbenzaldoxime with bromine. ${ }^{23}$ Other reagents and solvents were purchased from chemical suppliers and used without any further purification.

\section{Benzamide 2 and 1,2-Isoxazolidine 3 by Ene Reaction of (Nitroso- carbonyl)mesitylene (1M) with Crotyl Alcohol}

NMO (8.75 g, 1.5 equiv) was added to a stirred, ice-cooled solution of crotyl alcohol ( $21 \mathrm{~mL}, 5$ equiv) in $\mathrm{CH}_{2} \mathrm{Cl}_{2}(200 \mathrm{~mL})$. A solution of mesitonitrile oxide (MNO; $8.01 \mathrm{~g}, 50 \mathrm{mmol}$ ) in $\mathrm{CH}_{2} \mathrm{Cl}_{2}(200 \mathrm{~mL}$ ) was added dropwise and the reaction mixture was allowed to stir at r.t. for $24 \mathrm{~h}$. After dilution with an equivalent volume of $\mathrm{CH}_{2} \mathrm{Cl}_{2}$, the organic phase was washed with $\mathrm{H}_{2} \mathrm{O}$ and dried over anhydrous $\mathrm{Na}_{2} \mathrm{SO}_{4}$. After filtration, the solvent was evaporated and the reaction mixture was separated by column chromatography, affording the ene adducts $\mathbf{2}$ and $\mathbf{3}$, the latter as an inseparable mixture of diastereoisomers in the ratio $2: 1$. In the NMR data of $\mathbf{3}$ the signals of the minor diastereoisomer are reported in brackets.

\footnotetext{
$N$-Hydroxy- $N$-(1-hydroxybut-3-en-2-yl)-2,4,6-trimethylbenzamide (2)

Yield: $6.2 \mathrm{~g}$ (50\%); white crystals (EtOH); $\mathrm{mp} 137-140{ }^{\circ} \mathrm{C}$.

IR (Nujol): $3152(\mathrm{OH}), 1619(\mathrm{C}=\mathrm{O}) \mathrm{cm}^{-1}$.
}

${ }^{1} \mathrm{H}$ NMR (300 MHz, CDCl $): \delta=10.40$ (br s, $\left.1 \mathrm{H}, \mathrm{N}-\mathrm{OH}\right), 6.84(\mathrm{~s}, 2 \mathrm{H}$, $\mathrm{Ph}$ ), 5.95 (ddd, $J=17,11,9 \mathrm{~Hz}, 1 \mathrm{H},=\mathrm{CH}), 5.23\left(\mathrm{~d}, J=11 \mathrm{~Hz}, 1 \mathrm{H},=\mathrm{CH}_{2}\right)$, $5.08\left(\mathrm{~d}, J=17 \mathrm{~Hz}, 1 \mathrm{H},=\mathrm{CH}_{2}\right), 4.12\left(\mathrm{~m}, 1 \mathrm{H}, \mathrm{CH}_{2}-\mathrm{O}\right), 3.98(\mathrm{t}, J=9 \mathrm{~Hz}, 1$ $\mathrm{H}, \mathrm{CH}-\mathrm{N}), 3.34\left(\mathrm{~d}, \mathrm{~J}=8 \mathrm{~Hz}, 1 \mathrm{H}, \mathrm{CH}_{2}-\mathrm{OH}\right), 2.31\left(\mathrm{~s}, 3 \mathrm{H}, \mathrm{CH}_{3}\right), 2.19(\mathrm{~s}, 6 \mathrm{H}$, $\mathrm{CH}_{3}$ ).

${ }^{13} \mathrm{C}$ NMR $\left(75 \mathrm{MHz}, \mathrm{CDCl}_{3}\right): \delta=169.4(\mathrm{C}=\mathrm{O}), 139.0,135.1,134.4(\mathrm{Ar}-$ om.), $131.5\left(\mathrm{CH}_{2}=\right), 130.2,128.5$ (Arom.), 128.1, $118.8(\mathrm{CH}=), 66.2$ $\left(\mathrm{CH}_{2}\right), 61.2(\mathrm{CH}-\mathrm{N}), 21.0,19.4,18.8\left(\mathrm{CH}_{3}\right)$.

Anal. Calcd for $\mathrm{C}_{14} \mathrm{H}_{19} \mathrm{NO}_{3}$ (249.30): C, 67.44; H, 7.68; N, 5.62. Found: C, 67.45; H, 7.63; N, 5.65.

\section{5-Hydroxy-3-methyl-2-(2,4,6-trimethylbenzoyl)-1,2-isoxazoli- dine (3)}

Yield: $2.77 \mathrm{~g}$ (23\%); white crystals (EtOH); $\mathrm{mp} 134-137^{\circ} \mathrm{C}$.

IR (Nujol): $3284(\mathrm{OH}), 1639(\mathrm{C}=0) \mathrm{cm}^{-1}$.

${ }^{1} \mathrm{H}$ NMR $\left(300 \mathrm{MHz}, \mathrm{CDCl}_{3}\right): \delta=6.88$ [6.70] $(\mathrm{s}, 2 \mathrm{H}, \mathrm{Ph}), 5.89$ [5.46] (t, J = $4 \mathrm{~Hz}, 1 \mathrm{H}, \mathrm{O}-\mathrm{CH}-\mathrm{O}$ ), 3.98 [4.78] (quin, $J=6 \mathrm{~Hz}, 1 \mathrm{H}, \mathrm{N}-\mathrm{CH}$ ), 3.66 (br s, 1 $\mathrm{H}, \mathrm{OH}), 2.51[2.55]\left(\mathrm{m}, 1 \mathrm{H}, \mathrm{CH}_{2}\right), 2.30,2.32$ and $2.35\left(\mathrm{~s}, 9 \mathrm{H}, \mathrm{CH}_{3}\right), 2.03$ [2.08] ( $\left.\mathrm{m}, 1 \mathrm{H}, \mathrm{CH}_{2}\right), 1.03$ [1.48] (d, J = $\left.6 \mathrm{~Hz}, 3 \mathrm{H}, \mathrm{CH}_{3}\right)$.

${ }^{13} \mathrm{C}$ NMR (75 MHz, $\left.\mathrm{CDCl}_{3}\right): \delta=167.6$ [168.6] $(\mathrm{C}=0), 138.8$ [138.2], 134.8 [134.3], 131.8 [133.0], 128.1 [128.3], 127.7 [127.9] (Arom.), 98.3 [97.3] (CH-O), 53.3 [50.5] (CH-N), 43.2 [42.9] $\left(\mathrm{CH}_{2}\right), 21.0$ [20.2], 18.7 [19.1] $\left(\mathrm{CH}_{3}\right)$.

Anal. Calcd for $\mathrm{C}_{14} \mathrm{H}_{19} \mathrm{NO}_{3}$ (249.30): C, 67.44; H, 7.68; N, 5.62. Found: C, 67.46; H, 7.65; N, 5.64.

\section{5-Acetoxy-3-methyl-2-(2,4,6-trimethylbenzoyl)-1,2-isoxazolidine (6a,b)}

$\mathrm{Ac}_{2} \mathrm{O}$ (2.2 equiv), DMAP ( 0.34 equiv), and $\mathrm{Et}_{3} \mathrm{~N}$ ( 2.2 equiv) were added to a stirred, ice-cooled solution of $\mathbf{3}(1.26 \mathrm{~g}, 5.06 \mathrm{mmol})$ in anhydrous $\mathrm{CH}_{2} \mathrm{Cl}_{2}(150 \mathrm{~mL})$. The reaction mixture was allowed to stir at r.t. for 24 h. After dilution with an equivalent volume of $\mathrm{CH}_{2} \mathrm{Cl}_{2}$, the organic phase was washed with a saturated solution of $\mathrm{NaHCO}_{3}$ and dried over anhydrous $\mathrm{Na}_{2} \mathrm{SO}_{4}$. After filtration, the solvent was evaporated and an oily residue was obtained, corresponding to a mixture of the two diastereoisomers $\mathbf{6 a}, \mathbf{b}$. The acetyl derivatives $\mathbf{6 a}$ and $\mathbf{6 b}$ were then separated by column chromatography and fully characterized.

\section{1,2-Isoxazolidine 6a}

Yield: $0.57 \mathrm{~g}$ (45\%); white crystals (EtOH); mp 92-94 ${ }^{\circ} \mathrm{C}$.

IR (Nujol): 1760, $1669(\mathrm{C}=0) \mathrm{cm}^{-1}$.

$\left.{ }^{1} \mathrm{H} \mathrm{NMR} \mathrm{(300} \mathrm{MHz,} \mathrm{CDCl}_{3}\right): \delta=6.81(\mathrm{~s}, 2 \mathrm{H}, \mathrm{Ph}), 6.33(\mathrm{~d}, J=6 \mathrm{~Hz}, 1 \mathrm{H}$, O-CH-O), 4.65 (quin, $J=6 \mathrm{~Hz}, 1 \mathrm{H}, \mathrm{N}-\mathrm{CH}$ ), 2.25 and $2.20(\mathrm{~s}, 6 \mathrm{H}+3 \mathrm{H}$, $\left.\mathrm{CH}_{3}\right), 2.72$ and $2.25\left(\mathrm{~m}, 1 \mathrm{H}+1 \mathrm{H}, \mathrm{CH}_{2}\right), 2.06\left(\mathrm{~s}, 3 \mathrm{H}, \mathrm{CH}_{3} \mathrm{CO}\right), 1.63$ (d, $\left.J=6 \mathrm{~Hz}, 3 \mathrm{H}, \mathrm{CH}_{3}\right)$.

${ }^{13} \mathrm{C}$ NMR $\left(75 \mathrm{MHz}, \mathrm{CDCl}_{3}\right): \delta=169.0(\mathrm{C}=0), 168.8(\mathrm{C}=0), 138.3,134.4$, 133.6, 128.5, 128.2, 128.0, 127.9 (Arom.), $95.1(\mathrm{CH}-\mathrm{O}), 50.5(\mathrm{CH}-\mathrm{N})$, $40.3\left(\mathrm{CH}_{2}\right), 21.0,20.9,19.8,19.0,18.5\left(\mathrm{CH}_{3}\right)$.

Anal. Calcd for $\mathrm{C}_{16} \mathrm{H}_{21} \mathrm{NO}_{4}$ (291.34): C, 65.95; $\mathrm{H}, 7.27 ; \mathrm{N}, 4.81$. Found: C, 65.96; H, 7.25; N, 4.84.

\section{1,2-Isoxazolidine 6b}

Yield: $0.59 \mathrm{~g}(47 \%)$; yellowish oil. IR (Nujol): 1758, $1634(\mathrm{C}=0) \mathrm{cm}^{-1}$. 
${ }^{1} \mathrm{H}$ NMR $\left(300 \mathrm{MHz}, \mathrm{CDCl}_{3}\right): \delta=6.74(\mathrm{~s}, 2 \mathrm{H}, \mathrm{Ph}), 6.18(\mathrm{~d}, J=5 \mathrm{~Hz}, 1 \mathrm{H}$, O-CH-O), 4.62 (quin, $J=6 \mathrm{~Hz}, 1 \mathrm{H}, \mathrm{N}-\mathrm{CH}$ ), 2.53 and $2.19(\mathrm{~m}, 1 \mathrm{H}+1 \mathrm{H}$, $\left.\mathrm{CH}_{2}\right), 2.22$ and $2.20\left(\mathrm{~s}, 3 \mathrm{H}+6 \mathrm{H}, \mathrm{CH}_{3}\right), 1.90\left(\mathrm{~s}, 3 \mathrm{H}, \mathrm{CH}_{3} \mathrm{CO}\right), 1.43(\mathrm{~d}, J=$ $\left.6 \mathrm{~Hz}, 3 \mathrm{H}, \mathrm{CH}_{3}\right)$.

${ }^{13} \mathrm{C}$ NMR $\left(75 \mathrm{MHz}, \mathrm{CDCl}_{3}\right): \delta=169.0(\mathrm{C}=\mathrm{O}), 168.8(\mathrm{C}=\mathrm{O}), 138.4,134.4$, 133.6, 132.1, 127.9 (Arom.), 95.6 ( $\mathrm{CH}-\mathrm{O}), 50.2$ ( $\mathrm{CH}-\mathrm{N}), 42.1\left(\mathrm{CH}_{2}\right)$, 21.1, 21.0, 20.8, 19.3, $18.9\left(\mathrm{CH}_{3}\right)$.

Anal. Calcd for $\mathrm{C}_{16} \mathrm{H}_{21} \mathrm{NO}_{4}$ (291.34): C, 65.95; $\mathrm{H}, 7.27 ; \mathrm{N}, 4.81$. Found: C, 65.97; H, 7.24; N, 4.83 .

\section{5-[2,4(1H,3H)-Dioxopyrimidin-1-yl]-3-methyl-2-(2,4,6-trimethyl- benzoyl)-1,2-isoxazolidine (7a,b)}

A solution of uracil ( $0.20 \mathrm{~g}, 1.78 \mathrm{mmol}, 2$ equiv) and BSA (2 equiv) in anhydrous $\mathrm{CH}_{2} \mathrm{Cl}_{2}(20 \mathrm{~mL})$ was refluxed under a $\mathrm{N}_{2}$ atmosphere for 15-20 min until it became clear. It was then cooled to r.t. before a solution of isoxazolidine $\mathbf{6 a}$ or $\mathbf{6 b}(0.26 \mathrm{~g}, 0.89 \mathrm{mmol})$ in $\mathrm{CH}_{2} \mathrm{Cl}_{2}(10$ $\mathrm{mL}$ ) was added dropwise. The mixture was cooled to $0{ }^{\circ} \mathrm{C}$ and TMSOTf $(0.16 \mathrm{~mL}, 1$ equiv) was added. The mixture was refluxed under stirring overnight and finally quenched with a saturated solution of $\mathrm{NaHCO}_{3}(\mathrm{pH} 7$ ). The mixture was diluted with an equivalent volume of $\mathrm{CH}_{2} \mathrm{Cl}_{2}$ and washed with $\mathrm{H}_{2} \mathrm{O}$, before it was finally dried over $\mathrm{Na}_{2} \mathrm{SO}_{4}$. From the residue, nucleosides $\mathbf{7 a}$ and $\mathbf{7 b}$ were isolated after column chromatography $\left(\mathrm{CHCl}_{3}\right.$ and $\left.\mathrm{CHCl}_{3} / \mathrm{MeOH}\right)$ and fully characterized.

\section{Nucleoside 7a}

Yield: $0.15 \mathrm{~g}$ (49\% from 6a); $0.14 \mathrm{~g}$ (46\% from 6b); white solid (EtOH); $\mathrm{mp}>210{ }^{\circ} \mathrm{C}$ (dec.).

IR (Nujol): $3164(\mathrm{NH}), 1724,1669(\mathrm{C}=\mathrm{O}) \mathrm{cm}^{-1}$.

${ }^{1} \mathrm{H}$ NMR (300 MHz, DMSO): $\delta=11.33(\mathrm{~s}, 1 \mathrm{H}, \mathrm{NH}), 7.70(\mathrm{~d}, J=8 \mathrm{~Hz}, 1$ $\mathrm{H},=\mathrm{CH}-\mathrm{N}), 6.86(\mathrm{~s}, 2 \mathrm{H}, \mathrm{Ph}), 6.19(\mathrm{t}, J=8 \mathrm{~Hz}, 1 \mathrm{H}, \mathrm{O}-\mathrm{CH}-\mathrm{N}), 5.69(\mathrm{~d}, J=$ $8 \mathrm{~Hz}, 1 \mathrm{H}, \mathrm{CO}-\mathrm{CH}=), 4.67(\mathrm{~d}, J=7 \mathrm{~Hz}, 1 \mathrm{H}, \mathrm{CH}-\mathrm{N}), 2.93$ and $2.29(\mathrm{~m}, 1 \mathrm{H}$ $\left.+1 \mathrm{H}, \mathrm{CH}_{2}\right), 2.23$ and $2.19\left(\mathrm{~s}, 9 \mathrm{H}, \mathrm{CH}_{3}\right), 1.50\left(\mathrm{~d}, J=6 \mathrm{~Hz}, 3 \mathrm{H}, \mathrm{CH}_{3}\right)$.

${ }^{13} \mathrm{C}$ NMR (75 MHz, DMSO): $\delta=162.6,150.3$ (C=O), 139.8 (CH=), 137.0, 133.4, 127.7 (Arom.), 102.9 ( $\mathrm{CH}=), 84.1(\mathrm{CH}-\mathrm{O}), 52.6\left(\mathrm{CH}_{2}\right), 20.6,20.1$, $18.8,18.5\left(\mathrm{CH}_{3}\right)$.

Anal. Calcd for $\mathrm{C}_{18} \mathrm{H}_{21} \mathrm{~N}_{3} \mathrm{O}_{4}$ (343.37): C, 62.96; H, 6.16; N, 12.24 . Found: C, 62.89; H, 6.15; N, 12.25 .

\section{Nucleoside 7b}

Yield: $0.144 \mathrm{~g}$ ( $47 \%$ from 6a), $0.11 \mathrm{~g}$ (37\% from $\mathbf{6 b}$ ); white solid (EtOH); $\mathrm{mp}>210^{\circ} \mathrm{C}$ (dec.).

IR (Nujol): $3173(\mathrm{NH}), 1702,1637(\mathrm{C}=\mathrm{O}) \mathrm{cm}^{-1}$.

${ }^{1} \mathrm{H}$ NMR (300 MHz, DMSO): $\delta=11.33(\mathrm{~s}, 1 \mathrm{H}, \mathrm{NH}), 7.65(\mathrm{~d}, J=8 \mathrm{~Hz}, 1$ $\mathrm{H}$, =CH-N), $6.81(\mathrm{~s}, 2 \mathrm{H}, \mathrm{Ph}), 6.27$ (d, J = 6 Hz, $1 \mathrm{H}, \mathrm{O}-\mathrm{CH}-\mathrm{N}), 5.63$ (d, J = $8 \mathrm{~Hz}, 1 \mathrm{H}, \mathrm{CO}-\mathrm{CH}=), 4.84(\mathrm{~d}, J=7 \mathrm{~Hz}, 1 \mathrm{H}, \mathrm{CH}-\mathrm{N}), 2.95$ and $2.50(\mathrm{~m}, 1 \mathrm{H}$ $\left.+1 \mathrm{H}, \mathrm{CH}_{2}\right), 2.21,2.15$ and $1.98\left(\mathrm{~s}, 9 \mathrm{H}, \mathrm{CH}_{3}\right), 1.43\left(\mathrm{~d}, J=6 \mathrm{~Hz}, 3 \mathrm{H}, \mathrm{CH}_{3}\right)$. ${ }^{13} \mathrm{C}$ NMR (75 MHz, DMSO): $\delta=164.4,162.8,150.5$ (C=O), 140.9, 137.6, 133.6, 133.0, 132.6, 127.6 (Arom.), 101.9 (CH-O), 84.4 (CH-N), 51.0 $\left(\mathrm{CH}_{2}\right), 37.9,20.6,19.1,18.4\left(\mathrm{CH}_{3}\right)$.

Anal. Calcd for $\mathrm{C}_{18} \mathrm{H}_{21} \mathrm{~N}_{3} \mathrm{O}_{4}$ (343.37): C, 62.96; H, 6.16; N, 12.24. Found: C, 62.98; H, 6.17; N, 12.23 .

\section{5-(6-Chloro-7H-purin-7-yl)-3-methyl-2-(2,4,6-trimethylbenzoyl)- 1,2-isoxazolidine (8a,b)}

A solution of 6-chloropurine ( $0.32 \mathrm{~g}, 2.06 \mathrm{mmol}, 2$ equiv) and BSA (2 equiv) in anhydrous $\mathrm{CH}_{2} \mathrm{Cl}_{2}(20 \mathrm{~mL})$ was refluxed under $\mathrm{N}_{2}$ for $1 \mathrm{~h}$. An additional equivalent of BSA was added and the mixture was refluxed until it became clear. It was then cooled to r.t. before a solution of isoxazolidines $\mathbf{6 a , b}(0.30 \mathrm{~g}, 1.03 \mathrm{mmol})$ in $\mathrm{CH}_{2} \mathrm{Cl}_{2}(10 \mathrm{~mL})$ was added dropwise. The mixture was cooled to $0{ }^{\circ} \mathrm{C}$ and TMSOTf $(0.20 \mathrm{~mL}, 1$ equiv) was added. The reaction mixture was stirred under reflux overnight and finally quenched with a saturated solution of $\mathrm{NaHCO}_{3}$ (pH 7). The mixture was diluted with an equivalent volume of $\mathrm{CH}_{2} \mathrm{Cl}_{2}$ and washed with $\mathrm{H}_{2} \mathrm{O}$, before it was finally dried over $\mathrm{Na}_{2} \mathrm{SO}_{4}$. From the residue, nucleosides $\mathbf{8 a}$ and $\mathbf{8 b}$ were isolated by column chromatography $\left(\mathrm{CHCl}_{3}\right.$ and $\left.\mathrm{CHCl}_{3} / \mathrm{MeOH}\right)$ and fully characterized.

\section{Nucleoside 8a}

Yield: $0.13 \mathrm{~g}$ (33\% from $\mathbf{6 a , b}$ ); white solid (EtOH); mp 177-178 ${ }^{\circ} \mathrm{C}$. IR (Nujol): $1663(\mathrm{C}=\mathrm{O}), 1635(\mathrm{C}=\mathrm{N}) \mathrm{cm}^{-1}$.

${ }^{1} \mathrm{H}$ NMR (300 MHz, DMSO): $\delta=9.22(\mathrm{~s}, 1 \mathrm{H}, \mathrm{CH}=\mathrm{N}), 8.83(\mathrm{~s}, 1 \mathrm{H}$, $\mathrm{CH}=\mathrm{N}), 6.86(\mathrm{~s}, 1 \mathrm{H}, \mathrm{Ph}), 6.70(\mathrm{~s}, 1 \mathrm{H}, \mathrm{Ph}), 6.62(\mathrm{t}, 1 \mathrm{H}, J=6 \mathrm{~Hz}, \mathrm{O}-\mathrm{CH}-$ $\mathrm{N}), 4.75(\mathrm{~m}, 1 \mathrm{H}, \mathrm{CH}-\mathrm{N}), 3.21$ and $3.00\left(\mathrm{~m}, 1 \mathrm{H}+1 \mathrm{H}, \mathrm{CH}_{2}\right), 2.21$ and $1.94\left(\mathrm{~s}, 6 \mathrm{H}+3 \mathrm{H}, \mathrm{CH}_{3}\right), 1.55\left(\mathrm{~d}, \mathrm{~J}=6 \mathrm{~Hz}, 3 \mathrm{H}, \mathrm{CH}_{3}\right)$.

${ }^{13} \mathrm{C}$ NMR (75 MHz, DMSO): $\delta=162.0(\mathrm{C}=\mathrm{O}), 152.3,148.1(\mathrm{C}=\mathrm{N}), 142.6$, 137.7, 133.4, 133.2, 127.6, 127.5 (Arom.), $122.1(\mathrm{CH}-\mathrm{O}), 84.8(\mathrm{CH}-\mathrm{N})$, $52.6\left(\mathrm{CH}_{2}\right), 20.6,19.4,19.1,18.3\left(\mathrm{CH}_{3}\right)$.

Anal. Calcd for $\mathrm{C}_{19} \mathrm{H}_{20} \mathrm{~N}_{5} \mathrm{O}_{2} \mathrm{Cl}$ (385.84): C, 59.15; H, 5.22; N, 18.15. Found: C, 59.19; H, 5.25; N, 18.15 .

\section{Nucleoside 8b}

Yield: $0.16 \mathrm{~g}$ (40\% from 6a,b); white solid (EtOH); $\mathrm{mp}>210{ }^{\circ} \mathrm{C}$ (dec.). IR (Nujol): $1663(\mathrm{C}=\mathrm{O}), 1624(\mathrm{C}=\mathrm{N}) \mathrm{cm}^{-1}$.

${ }^{1} \mathrm{H}$ NMR (300 MHz, DMSO): $\delta=8.90$ [8.96] (s, $\left.1 \mathrm{H}, \mathrm{CH}=\mathrm{N}\right), 8.73$ [8.89] $(\mathrm{s}, 1 \mathrm{H}, \mathrm{CH}=\mathrm{N}), 6.76$ and 6.43 [6.93 and 6.89] (s, $2 \mathrm{H}, \mathrm{Ph}), 6.65$ [6.88] (d, $J=7 \mathrm{~Hz}, 1 \mathrm{H}, \mathrm{O}-\mathrm{CH}-\mathrm{N}$ ), 5.10 [4.15] (quin, $J=8 \mathrm{~Hz}, 1 \mathrm{H}, \mathrm{CH}-\mathrm{N}$ ), 2.75 [2.75] and 3.55 [3.68] $\left(\mathrm{m}, 1 \mathrm{H}+1 \mathrm{H}, \mathrm{CH}_{2}\right), 1.11,2.11$ and 2.16 [1.89, 2.18 and 2.24] (s, $\left.9 \mathrm{H}, \mathrm{CH}_{3}\right), 1.51$ [1.06] (d, $\left.J=6 \mathrm{~Hz}, 3 \mathrm{H}, \mathrm{CH}_{3}\right)$.

${ }^{13} \mathrm{C}$ NMR (75 MHz, DMSO): $\delta=165.1$ [164.9] (C=0), 151.9 [151.6], 149.4, 146.1 [145.6] (C=N), 137.5, 133.7 [131.9], 132.6 [131.2], 127.6 [128.8] (Arom.), 127.2 [128.2] (CH-O), 83.6 [84.5] (CH-N), 51.1 [54.2] $\left(\mathrm{CH}_{2}\right), 20.5$ [21.0], 19.5, 18.5 [18.7], $17.2\left(\mathrm{CH}_{3}\right)$.

Anal. Calcd for $\mathrm{C}_{19} \mathrm{H}_{20} \mathrm{~N}_{5} \mathrm{O}_{2} \mathrm{Cl}$ (385.84): C, 59.15; H, 5.22; N, 18.15 . Found: C, 59.14; H, 5.24; N, 18.14 .

\section{Biological Tests}

Primary screen (dose response): determination of a $90 \%$ inhibitory concentration (IC90). The initial screen was conducted against Mycobacterium tuberculosis H37Rv (ATCC 27294) in BACTEC 12B medium by using the Microplate Alamar Blue Assay (MABA). The compounds were tested in ten twofold dilutions, typically from $100 \mu \mathrm{g} / \mathrm{mL}$ to 0.19 $\mu \mathrm{g} / \mathrm{mL}$. The IC90 is defined as the concentration effecting a reduction in fluorescence of $90 \%$ relative to controls. This value was determined from the dose-response curve using a curve-fitting program. Any IC90 value of $\geq 10 \mu \mathrm{g} / \mathrm{mL}$ is considered 'active' for antitubercular activity. For further information, consult the URL http://www.taacf.org.

\section{X-ray Crystallography}

A summary of the crystal data, data collection, and structures refinement of compounds $\mathbf{3}$ and 8aN7 are given in Tables S1-S3 of the Supporting Information. The structures are solved by direct methods; non-hydrogen atoms were refined anisotropically, and hydrogen atoms, located from the difference Fourier synthesis, were refined isotropically. ${ }^{24,25}$ CCDC 964611 and 964612 contain the supplementary 
crystallographic data for $\mathbf{3}$ and $\mathbf{8 a N 7}$, respectively. These data can be obtained free of charge from The Cambridge Crystallographic Data Centre via www.ccdc.cam.ac.uk/data_request/cif.

\section{Acknowledgment}

Financial support by the University of Pavia, MIUR (PRIN 2011, CUP: B11J12002450001) and Steroid S.p.a. - V.le Spagna, 156, 20093 Cologno Monzese (MI), Italy is gratefully acknowledged. Thanks are also due to the Consorzio Interuniversitario Nazionale Metodologie e Processi Innovativi di Sintesi (CINMPIS) for research support. We warmly thank Dr. J. Noah (SRI) for the biological tests.

\section{Supporting Information}

Supporting information for this article is available online at http://dx.doi.org/10.1055/s-0036-1588695.

\section{References}

(1) (a) Quadrelli, P.; Mella, M.; Carosso, S.; Bovio, B. J. Org. Chem. 2013, 78, 516. (b) Baidya, M.; Yamamoto, H. Synthesis 2013, 45 , 1931.

(2) (a) Chiacchio, U.; Corsaro, A.; Giofrè, S.; Romeo, G. Isoxazolidinyl Nucleosides, In Chemical Synthesis of Nucleoside Analogues; Merino, P., Ed.; Wiley: Hoboken, 2013. (b) Romeo, R.; Giofrè, S. V.; Carnovale, C.; Chiacchio, M. A.; Campisi, A.; Mancuso, R.; Cirmi, S.; Navarra, M. Eur. J. Org. Chem. 2014, 5442. (c) Romeo, R.; Navarra, M.; Giofrè, S. V.; Carnovale, C.; Cirmi, S.; Lanza, G.; Chiacchio, M. A. Bioorg. Med. Chem. 2014, 22, 3379. (d) Romeo, R.; Carnovale, C.; Giofrè, S. V.; Moncino, G.; Chiacchio, M. A.; Sanfilippo, C.; Macchi, B. Molecules 2014, 19, 14406. (e) Romeo, R.; Giofrè, S. V.; Carnovale, C.; Campisi, A.; Parenti, R.; Bandini, L.; Chiacchio, M. A. Bioorg. Med. Chem. 2013, 21, 7929. (f) Iannazzo, D.; Brunaccini, E.; Giofrè, S. V.; Piperno, A.; Romeo, G.; Ronsisvalle, S.; Chiacchio, M. A.; Lanza, G.; Chiacchio, U. Eur. J. Org. Chem. 2010, 5897. (g) Romeo, R.; Carnovale, C.; Giofrè, S. V.; Romeo, G.; Macchi, B.; Frezza, C.; Marino-Merlo, F.; Pistarà, V.; Chiacchio, U. Bioorg. Med. Chem. 2012, 20, 3652. (h) Romeo, R.; Giofrè, S. V.; Iaria, D.; Sciortino, M. T.; Ronsisvalle, S.; Chiacchio, M. A.; Scala, A. Eur. J. Org. Chem. 2011, 5690. (i) Kasiganesan, H.; Wright, G. L.; Chiacchio, M. A.; Gumina, G. Bioorg. Med. Chem. 2009, 17, 5347.

(3) Bortolini, O.; De Nino, A.; Elioseo, T.; Gavioli, R.; Maiuolo, L.; Russo, B.; Sforza, F. Bioorg. Med. Chem. 2010, 18, 6970.

(4) (a) Boutureira, O.; Isabel Matheu, M.; Diaz, Y.; Castillon, S. Chem. Soc. Rev. 2013, 42, 5056. (b) Grove, K. L.; Guo, X.; Lui, S. H.; Gao, Z.; Chu, C. K.; Cheng, Y. C. Cancer Res. 1995, 55, 3008. (c) Chang, C. N.; Doong, S. L.; Zhou, J. H.; Beach, J. W.; Jeong, L. S.; Chu, C. K.; Tsai, C. H.; Cheng, Y. C. J. Biol. Chem. 1992, 267, 13938.

(5) (a) Pistarà, V.; Corsaro, A.; Chiacchio, M. A.; Greco, G.; Quadrelli, P. ARKIVOC 2011, (vi), 270. (b) Chiacchio, U.; Genovese, F.; Iannazzo, D.; Piperno, A.; Quadrelli, P.; Corsaro, A.; Romeo, R.; Valveri, V.; Mastino, A. Bioorg. Med. Chem. 2004, 12, 3903. (c) Chiacchio, U.; Genovese, F.; Iannazzo, D.; Librando, V.; Merino, P.; Rescifina, A.; Romeo, R.; Propopio, A.; Romeo, G. Tetrahedron 2004, 60, 441. (d) Saita, M. G.; Chiacchio, U.; Iannazzo, D.; Merino, P.; Piperno, A.; Previtera, T.; Rescifina, A.; Romeo, G.; Romeo, R. Nucleosides, Nucleotides Nucleic Acids 2003, 22,
739. (e) Chiacchio, U.; Corsaro, A.; Iannazzo, D.; Piperno, A.; Pistarà, V.; Rescifina, A.; Romeo, A.; Valveri, V.; Mastino, A.; Romeo, G. J. Med. Chem. 2003, 46, 3696.

(6) (a) Quadrelli, P.; Gamba Invernizzi, A.; Caramella, P. Tetrahedron Lett. 1996, 37, 1909. (b) Quadrelli, P.; Mella, M.; Gamba Invernizzi, A.; Caramella, P. Tetrahedron 1999, 55, 10497.

(7) Fukuda, S.; Kamimura, A.; Kanemasa, S.; Hori, K. Tetrahedron 2000, 56, 1637.

(8) (a) Quadrelli, P.; Mella, M.; Piccanello, A.; Romano, S.; Caramella, P. J. Org. Chem. 2007, 72, 1807. (b) Quadrelli, P.; Romano, S.; Piccanello, A.; Caramella, P. J. Org. Chem. 2009, 74, 2301. (c) Adam, W.; Krebs, O. Chem. Rev. 2003, 103, 4131.

(9) Quadrelli, P.; Mella, M.; Carosso, S.; Bovio, B. Synthesis 2013, 45, 1414.

(10) Quadrelli, P.; Mella, M.; Caramella, P. Tetrahedron Lett. 1998, 39, 3233.

(11) (a) Motorina, I. A.; Sviridova, L. A.; Golubeva, G. A.; Bundel, Y. G. Tetrahedron Lett. 1989, 30, 117. (b) Motorina, I. A.; Sviridova, L. A.; Golubeva, G. A.; Bundel, Y. G. Khim. Geterotsikl. Soedin. 1990, 976.

(12) (a) Vorbrüggen, H.; Krolikiewicz, K.; Bennua-Skalmowski, B. US Patent 5,750,676, 1998. (b) Vorbrüggen, H.; Krolikiewicz, K.; Bennua, B. Chem. Ber. 1981, 114, 1234. (c) Vorbrüggen, H.; Höfle, G. Chem. Ber. 1981, 114, 1256. (d) Vorbrüggen, H.; Bennua, B. Chem. Ber. 1981, 114, 1279.

(13) (a) Chiacchio, U.; Corsaro, A.; Iannazzo, D.; Piperno, A.; Pistarà, V.; Procopio, A.; Rescifina, A.; Romeo, G.; Romeo, R.; Siciliano, M. C. R.; Valveri, E. ARKIVOC 2002, (x), 159. (b) Gotkowska, J.; Balzarini, J.; Piotrowska, D. G. Tetrahedron Lett. 2012, 53, 7097.

(14) For acetylation of 5-hydroxyisoxazolidines, see: (a) Xiang, Y.; Gong, Y.; Zhao, K. Tetrahedron Lett. 1996, 37, 4877. (b) Zhang, X.; Qing, F.-L.; Yu, Y. J. Org. Chem. 2000, 65, 7075. (c) Zhang, X.; Xia, H.; Dong, X.; Jin, J.; Meng, W.-D.; Qing, F.-L. J. Org. Chem. 2003, 68, 9026.

(15) Yoshimura, Y.; Kitano, K.; Yamada, K.; Satoh, H.; Watanabe, M.; Miura, S.; Sakata, S.; Sasaki, T.; Matsuda, A. J. Org. Chem. 1997, $62,3140$.

(16) Caddell, J. M.; Chapman, A. M.; Cooley, B. E.; Downey, B. P.; LeBlanc, M. P.; Jackson, M. M.; O'Connell, T. M.; Phung, H.-M.; Roper, T. D.; Xie, S. J. Org. Chem. 2004, 69, 3112.

(17) (a) Kitade, Y.; Kojima, H.; Zulfiqur, F.; Kim, H. S.; Wataya, Y. Bioorg. Med. Chem. Lett. 2003, 13, 3963. (b) Ramesh, N. G.; Klunder, A. J. H.; Zwanenburg, B. J. Org. Chem. 1999, 64, 3635. (c) Wu, J.; Schneller, S. W.; Seley, K. L.; DeClerq, E. Heterocycles 1998, 47, 757. (d) Siddiqi, S. M.; Raissian, M.; Schneller, S. W.; Ikeda, S.; Snoeck, R.; Andrei, G.; Balzarini, J.; DeClerq, E. Bioorg. Med. Chem. Lett. 1993, 3, 663. (e) Da Silva, A. D.; Coimbra, E. S.; Fourrey, J. L.; Machado, A. S.; Robert-Gero, M. Tetrahedron Lett. 1993, 34, 6745. (f) Koga, M.; Schneller, S. W. Tetrahedron Lett. 1990, 31, 5861 .

(18) (a) Chiacchio, U.; Saita, M. G.; Crispino, L.; Gumina, G.; Mangiafico, S.; Pistarà, V.; Romeo, G.; Piperno, A.; De Clercq, E. Tetrahedron 2006, 62, 1171. (b) Chiacchio, U.; Iannazzo, D.; Piperno, A.; Romeo, R.; Romeo, G.; Rescifina, A.; Saglimbeni, M. Bioorg. Med. Chem. 2006, 14, 955.

(19) For a survey on nucleoside synthesis, see: Vorbrüggen, H.; RuhPohlenz, C. Handbook of Nucleoside Synthesis; Wiley: New York, 2001.

(20) Caramella, P.; Grünager, P. 1,3-Dipolar Cycloaddition Chemistry; Vol.1; Padwa, A., Ed.; Wiley: New York, 1984, 291-392; and references cited therein. 
Synthesis

(21) (a) Gonzalez, M. P.; Teran, C.; Fall, Y.; Teijeira, M.; Besada, P. Bioorg. Med. Chem. 2005, 13, 601. (b) Tchilibon, S.; Joshi, B. V.; Kim, S.-K.; Duong, H. T.; Gao, Z.-G.; Jacobson, K. A. J. Med. Chem. 2005, 48, 1745. (c) Joshi, B. V.; Moon, H. R.; Fettinger, J. C.; Marquez, V. E.; Jacobson, K. A. J. Org. Chem. 2005, 70, 439.

(22) Collins, L. A.; Franzblau, S. G. Antimicrob. Agents Chemother. 1997, 41, 1004.

(23) (a) Grundmann, C.; Grünanger, P. The Nitrile Oxide; Springer: Heidelberg, 1971. (b) Grundmann, C.; Dean, J. M. J. Org. Chem. 1965, 30, 2809.

(24) North, A. C. T.; Phillips, D. C.; Mathews, F. S. Acta Crystallogr., Sect. A 1968, 24, 351.

(25) (a) Sheldrick, G. M. SHELXL-93: Program for Crystal Structure Analysis; University of Göttingen: Germany, 1993. (b) Johnson, C. K. ORTEP Report ORNL-3793; Oak Ridge National Laboratory: TN, 1965. 